Original Research Paper

\title{
Standardized Ileal Digestible Lysine Requirement of 6- to 10-kg Weanling Pigs
}

\author{
Chan Sol Park and Beob Gyun Kim \\ Department of Animal Science and Technology, Konkuk University, Seoul, Republic of Korea
}

\author{
Article history \\ Received: 01-4-2015 \\ Revised: 10-4-2015 \\ Accepted: 16-5-2015 \\ Corresponding Author: \\ Beob Gyun Kim \\ Department of Animal Science \\ and Technology, Konkuk \\ University, Seoul, Republic of \\ Korea \\ Email: bgkim@konkuk.ac.kr
}

\begin{abstract}
The objective of the experiment was to determine the Standardized Ileal Digestible (SID) lysine requirement for weanling pigs from 6 to $10 \mathrm{~kg}$ of Body Weight (BW). A total of 216 weanling pigs with an initial $\mathrm{BW}$ of $6.23 \pm 0.93 \mathrm{~kg}$ were assigned to six diets in a randomized complete block design with five blocks based on BW. Six corn-dried wheysoybean meal-based diets were formulated to contain 6 concentrations of SID lysine from 1.17 to $1.62 \%$ with an increment of $0.09 \%$ at the expense of corn. Pigs were fed experimental diets during 14 days of trial and BW of pigs and feed intake were recorded on day 7 and 14. During the first 7 days, average daily gain, Average Daily Feed Intake (ADFI) and Gain:Feed (G:F) of pigs were not affected by the dietary SID lysine concentration. However, the ADFI of pigs linearly decreased $(\mathrm{p}=0.002)$ as the SID lysine concentration increased during the following 7 days. During the overall period, the addition of dietary SID lysine linearly decreased $(p=0.007)$ ADFI whereas linearly increased $(p=0.011)$ G:F. The SID lysine requirement was determined by four different statistical analyses including linear broken-line model, quadratic broken-line model, $95 \%$ of the upper asymptotic value of quadratic model and the former intercept between plateau of the linear broken-line model and quadratic model. Mean value for the SID lysine requirement was $1.43 \%$ (4.07 $\mathrm{g} / \mathrm{Mcal}$ metabolizable energy), ranged from 1.39 to $1.49 \%$ (from 3.95 to $4.24 \mathrm{~g} / \mathrm{Mcal}$ metabolizable energy) based on G:F of pigs from 6 to $10 \mathrm{~kg}$ of BW.
\end{abstract}

Keywords: Amino Acid, Broken-Line Analysis, Growth Performance, Swine

\section{Introduction}

Lysine is generally the first-limiting Amino Acid (AA) in corn-soybean meal-based swine diets and thus, the lysine requirement is traditionally considered as the standard for the other AA requirements (Wang and Fuller, 1989; Chung and Baker, 1992; NRC, 2012). Stein et al. (2007) and Kong and Adeola (2014) suggested that dietary AA concentration should be expressed as Standardized Ileal Digestible (SID) AA in order to appropriately represent the available AA contents in feed ingredients and diets. Based on these concepts, NRC (2012) suggested estimates of dietary lysine requirement as SID lysine concentration; however, the SID lysine requirement for weanling pigs were estimated not by using growth model based on various biological approaches but by using empirical approach because of the lack of information.
The empirical approach employed in NRC (2012) was based on regression analysis for the SID lysine requirement observed in previous experiments relative to Body Weight (BW) of pigs from 5 to $20 \mathrm{~kg}$. However, accuracy of this approach is questionable because the empirical approach did not consider various factors affecting the SID lysine requirement such as conversion of nutrient to body composition (de Lange et al., 2001), gender (Cromwell et al., 1993), genotype (Schneider et al., 2010) and voluntary feed intake predicted by energy concentration in diets (Kil et al., 2013).

After revised edition of NRC (2012) was published, few experiments were conducted to determine the SID lysine requirement for weanling pigs (Nemechek et al., 2012; Jones et al., 2014). Moreover, the information on SID lysine requirements for weanling pigs is still insufficient to evaluate the estimates of SID lysine requirement for weanling pigs. Therefore, the objective of this 
experiment was to determine the SID lysine requirement for weanling pigs from 6 to $10 \mathrm{~kg}$ of $\mathrm{BW}$.

\section{Materials and Methods}

\section{Animals and Experimental Design}

The present experiment was reviewed and approved by the Institutional Animal Care and Use Committee at the Konkuk University.

A total of 216 crossbred piglets were weaned at approximately 21 days (d) of age with a mean BW of $6.00 \pm 0.77 \mathrm{~kg}$. Pigs were fed a commercial diet for $8 \mathrm{~d}$ before the experimental period. At the beginning of the experiment, pigs were assigned to six dietary treatments in a randomized complete block design with five blocks based on BW using a spreadsheet program developed by Kim and
Lindemann (2007). Each dietary treatment consisted of three replicate pens with six pigs per pen and two replicate pens with nine pigs per pen. Sex was balanced within replicate. Each pen was equipped with a feeder and two nipple drinkers. Pigs had free access to feed and water.

\section{Experimental Diets}

Six experimental diets mainly based on ground corn, dried whey, soybean meal, spray-dried plasma protein and fish meal were prepared (Table 1). Diets were formulated on an SID basis using ingredient SID AA concentrations provided by NRC (2012). Experimental diets contained 6 concentrations of SID lysine from 1.17 to $1.62 \%$ with an increment of $0.09 \%$ by adding crystalline ${ }_{\mathrm{L}}$-lysine $\cdot \mathrm{HCl}$ at the expense of ground corn.

Table 1. Ingredient and calculated nutrient composition of experimental diets (as-fed basis)

\begin{tabular}{|c|c|c|c|c|c|c|}
\hline \multirow[b]{2}{*}{ Item } & \multicolumn{6}{|c|}{ SID $^{\mathrm{a}}$ lysine $(\%)$} \\
\hline & 1.17 & 1.26 & 1.35 & 1.44 & 1.53 & 1.62 \\
\hline \multicolumn{7}{|l|}{ Ingredient (\%) } \\
\hline Ground corn & 48.0 & 47.7 & 47.4 & 47.2 & 46.9 & 46.6 \\
\hline Soybean meal, $48 \%$ crude protein & 18.0 & 18.0 & 18.0 & 18.0 & 18.0 & 18.0 \\
\hline Dried whey & 20.0 & 20.0 & 20.0 & 20.0 & 20.0 & 20.0 \\
\hline Spray-dried plasma protein ${ }^{b}$ & 4.00 & 4.00 & 4.00 & 4.00 & 4.00 & 4.00 \\
\hline Fish meal & 5.00 & 5.00 & 5.00 & 5.00 & 5.00 & 5.00 \\
\hline Soybean oil & 3.00 & 3.00 & 3.00 & 3.00 & 3.00 & 3.00 \\
\hline Ground limestone & 1.10 & 1.10 & 1.10 & 1.10 & 1.10 & 1.10 \\
\hline Dicalcium phosphate & 0.12 & 0.12 & 0.12 & 0.12 & 0.12 & 0.12 \\
\hline Salt & 0.30 & 0.30 & 0.30 & 0.30 & 0.30 & 0.30 \\
\hline Vitamin premix & 0.10 & 0.10 & 0.10 & 0.10 & 0.10 & 0.10 \\
\hline Mineral premix ${ }^{\mathrm{d}}$ & 0.20 & 0.20 & 0.20 & 0.20 & 0.20 & 0.20 \\
\hline $\mathrm{L}^{-\mathrm{Lysine}} \cdot \mathrm{HCl}$ & 0.00 & 0.11 & 0.23 & 0.34 & 0.46 & 0.57 \\
\hline $\mathrm{DL}^{-M e t h i o n i n e}$ & 0.14 & 0.20 & 0.26 & 0.32 & 0.38 & 0.45 \\
\hline $\mathrm{L}^{-}$-Threonine & 0.09 & 0.16 & 0.22 & 0.29 & 0.36 & 0.42 \\
\hline $\mathrm{L}^{-}$-Tryptophan & 0.00 & 0.02 & 0.04 & 0.06 & 0.08 & 0.10 \\
\hline Total & 100.0 & 100.0 & 100.0 & 100.0 & 100.0 & 100.0 \\
\hline \multicolumn{7}{|l|}{ Calculated nutrient $\mathrm{e}^{\mathrm{e}}(\%)$} \\
\hline Metabolizable energy, $\mathrm{kcal} / \mathrm{kg}$ & 3,509 & 3,512 & 3,515 & 3,518 & 3,521 & 3,524 \\
\hline Crude protein & 21.3 & 21.5 & 21.7 & 21.8 & 22.0 & 22.2 \\
\hline Calcium & 0.84 & 0.84 & 0.84 & 0.84 & 0.84 & 0.84 \\
\hline Phosphorus & 0.61 & 0.61 & 0.61 & 0.61 & 0.61 & 0.61 \\
\hline STTD $^{\mathrm{f}}$ phosphorus & 0.42 & 0.42 & 0.42 & 0.42 & 0.42 & 0.42 \\
\hline \multicolumn{7}{|l|}{ Total amino acid (\%) } \\
\hline Lysine & 1.33 & 1.42 & 1.51 & 1.60 & 1.69 & 1.78 \\
\hline Methionine & 0.49 & 0.55 & 0.61 & 0.68 & 0.74 & 0.80 \\
\hline Methionine + Cysteine & 0.90 & 0.96 & 1.02 & 1.08 & 1.14 & 1.20 \\
\hline Threonine & 1.01 & 1.07 & 1.14 & 1.20 & 1.27 & 1.33 \\
\hline Tryptophan & 0.28 & 0.29 & 0.31 & 0.33 & 0.35 & 0.37 \\
\hline \multicolumn{7}{|l|}{ SID amino acid (\%) } \\
\hline Lysine & 1.17 & 1.26 & 1.35 & 1.44 & 1.53 & 1.62 \\
\hline Methionine & 0.45 & 0.51 & 0.57 & 0.63 & 0.69 & 0.75 \\
\hline Methionine + Cysteine & 0.79 & 0.85 & 0.91 & 0.97 & 1.03 & 1.09 \\
\hline Threonine & 0.85 & 0.92 & 0.98 & 1.05 & 1.11 & 1.18 \\
\hline Tryptophan & 0.25 & 0.26 & 0.28 & 0.30 & 0.32 & 0.34 \\
\hline
\end{tabular}

${ }^{\mathrm{a}} \mathrm{SID}=$ Standardized Ileal Digestible

${ }^{\mathrm{b}}$ APC920, APC, Ames, IA

${ }^{\mathrm{c}}$ Provided the following quantities per $\mathrm{kg}$ of complete diet: Vitamin A, 25,000 IU; vitamin E, $40 \mathrm{IU}$; niacin, $40 \mathrm{mg} / \mathrm{kg}$; ascorbic acid, $85 \mathrm{mg} / \mathrm{kg}$

${ }^{\mathrm{d}}$ Provided as milligrams per $\mathrm{kg}$ of complete diet: cobalt, $0.41 \mathrm{mg}$ as cobalt sulfate; copper, 63.1 as copper sulfate; iodine, 0.82 as 0 calcium iodide; iron, 110 as iron sulfate; manganese, 62.9 as manganese sulfate; selenium, 0.21 as sodium selenite; zinc, 41.6 as zinc sulfate

${ }^{\mathrm{e}}$ The concentrations of nutrients were derived from values suggested in NRC (2012)

${ }_{\mathrm{f}}^{\mathrm{S} T T D}=$ Standardized Total Tract Digestible 
Crystalline ${ }_{\text {DL-methionine, }}$-threonine and ${ }_{\mathrm{L}}$-tryptophan were gradually added in each experimental diet in order to sufficiently meet the dietary SID AA to lysine ratios ( 0.671 for methionine + cysteine, 0.727 for threonine and 0.210 for tryptophan relative to lysine). Diets were formulated to meet or exceed the requirement estimates for other SID AA, minerals and vitamins recommended in NRC (2012). Calculated Metabolizable Energy (ME) concentrations in diets ranged from 3,509 to 3,524 $\mathrm{kcal} / \mathrm{kg}$. Two experimental diets, containing $1.17 \%$ SID lysine and $1.62 \%$ SID lysine, were prepared and these two diets were blended to achieve the intermediate four diets.

\section{Measurements and Chemical Analysis}

On $\mathrm{d} 7$ and 14, individual BW of pig and consumed diet in each pen were recorded. The Average Daily Gain (ADG), Average Daily Feed Intake (ADFI) and Gain:Feed (G:F) were calculated by mean BW of pigs and consumed diet in each pen during the $14 \mathrm{~d}$ of trial.

Experimental diets were analyzed for Crude Protein (CP; AOAC, 2005; method 990.03), calcium (AOAC, 2005; method 978.02) and phosphorus (AOAC, 2005; method 946.06). The concentrations of AA in experimental diets were analyzed by HPLC after post-column derivatization (AOAC, 2005; method 982.30 E [a, b, c]). Diet samples were prepared by a 24-h hydrolysis in $6 \mathrm{~N}$ $\mathrm{HCl}$ at $110^{\circ} \mathrm{C}$ under an atmosphere of N. For methionine and cysteine, samples were analyzed as methionine sulfone and cysteic acid after cold performic acid oxidation before hydrolysis. For analysis of tryptophan, samples were hydrolyzed by barium hydroxide.

\section{Statistical Analysis}

Data were analyzed by ANOVA using GLM procedure of SAS (SAS Inst. Inc., Cary, NC). Model included dietary SID lysine concentration and block as independent variables. Orthogonal polynomial contrast was used to analyze linear and quadratic effects of dietary SID lysine concentration. Least squares means for each response variable were calculated and the experimental unit was the pen.
The optimal SID lysine requirements were estimated by four different regression analyses between the G:F of pigs during the overall period and dietary SID lysine concentration, all of which were analyzed by NLIN procedure of SAS. The optimal SID lysine requirement was determined by linear and quadratic broken-line analyses (Robbins et al., 2006). Quadratic model was also used to estimate the requirement; in this approach, 95\% of the upper asymptotic value was applied (Baker, 1986). Based on the assumption suggested by Parr et al. (2003), the SID lysine requirement was also obtained by the former intercept between plateau of the linear broken-line model and quadratic model. In all statistical analyses, significance of the model was declared at $\mathrm{p}<0.05$.

\section{Results}

The concentrations of $\mathrm{CP}$ and total lysine were in agreement with the calculated concentrations in experimental diets (Table 2). Therefore, calculated values were used to analyze the growth performance data and to determine the SID lysine requirement of weanling pigs. During the overall experimental period, all pigs were in good health and condition except one fed the diet containing $1.62 \%$ SID lysine, which was removed on d 10 and the data were adjusted when calculating ADG, ADFI and G:F using the individual feed intake estimation procedure (Lindemann and Kim, 2007).

Mean BW of pigs on d 0 and 14 was 6.2 and $10.3 \mathrm{~kg}$, respectively (Table 3). Significant differences among treatments were not observed in ADG, ADFI and G:F for the first $7 \mathrm{~d}$ of trial. From $\mathrm{d} 7$ to 14 , however, there was a linear decrease $(p=0.002)$ in ADFI of pigs as dietary SID lysine concentration increased. During the overall experimental period, the addition of dietary SID lysine linearly decreased $(p=0.007)$ ADFI whereas linearly increased $(\mathrm{p}=0.011) \mathrm{G}: \mathrm{F}$.

Using the mean values for the G:F of pigs during the overall period, the SID lysine requirements were estimated by four different approaches. Linear brokenline analysis indicated that the optimal SID lysine requirement (i.e., break point value) was $1.39 \%$ (Fig. 1a).

Table 2. Analyzed nutrient and total amino acid concentrations in experimental diets (as-fed basis)

\begin{tabular}{|c|c|c|c|c|c|c|}
\hline \multirow[b]{2}{*}{ Item } & \multicolumn{6}{|c|}{ SID $^{\mathrm{a}}$ lysine (\%) } \\
\hline & 1.17 & 1.26 & 1.35 & 1.44 & 1.53 & 1.62 \\
\hline \multicolumn{7}{|l|}{ Analyzed nutrient (\%) } \\
\hline Crude protein & 22.7 & 21.9 & 22.2 & 22.0 & 23.0 & 22.6 \\
\hline Calcium & 0.82 & 0.89 & 0.83 & 0.85 & 0.86 & 0.87 \\
\hline Phosphorus & 0.59 & 0.60 & 0.58 & 0.58 & 0.58 & 0.60 \\
\hline \multicolumn{7}{|l|}{ Total amino acid (\%) } \\
\hline Lysine & 1.45 & 1.47 & 1.56 & 1.60 & 1.91 & 1.72 \\
\hline Methionine & 0.48 & 0.59 & 0.53 & 0.62 & 0.63 & 0.69 \\
\hline Methionine + Cysteine & 1.00 & 1.11 & 1.05 & 1.13 & 1.15 & 1.23 \\
\hline Threonine & 1.06 & 1.12 & 1.18 & 1.16 & 1.27 & 1.35 \\
\hline Tryptophan & 0.20 & 0.11 & 0.19 & 0.16 & 0.07 & 0.10 \\
\hline
\end{tabular}

${ }^{\mathrm{a}} \mathrm{SID}=$ Standardized Ileal Digestible 
Table 3. Effects of Standardized Ileal Digestible (SID) lysine on growth performance of weanling pigs ${ }^{\mathrm{a}}$

\begin{tabular}{|c|c|c|c|c|c|c|c|c|c|}
\hline \multirow[b]{2}{*}{ Item $^{\mathrm{c}}$} & \multicolumn{6}{|c|}{ SID $^{\mathrm{b}}$ lysine $(\%)$} & \multicolumn{3}{|l|}{ p-value } \\
\hline & 1.17 & 1.26 & 1.35 & 1.44 & 1.53 & 1.62 & $\mathrm{SEM}^{\mathrm{d}}$ & Linear & Quadratic \\
\hline \multicolumn{10}{|c|}{ Body weight (kg) } \\
\hline day 0 & 6.170 & 6.180 & 6.160 & 6.170 & 6.160 & 6.150 & 0.010 & 0.250 & 0.345 \\
\hline day 7 & 7.990 & 8.080 & 7.910 & 7.910 & 8.120 & 7.960 & 0.110 & 0.975 & 0.756 \\
\hline $\begin{array}{l}\text { day } 14 \\
\text { day } 0 \text { to } 7\end{array}$ & 10.400 & 10.400 & 10.400 & 10.200 & 10.300 & 10.200 & 0.200 & 0.390 & 0.973 \\
\hline $\mathrm{ADG}, \mathrm{g} / \mathrm{d}$ & 261.000 & 271.000 & 249.000 & 248.000 & 280.000 & 259.000 & 16.000 & 0.918 & 0.678 \\
\hline ADFI, g/d & 319.000 & 317.000 & 298.000 & 307.000 & 316.000 & 306.000 & 10.000 & 0.495 & 0.433 \\
\hline $\begin{array}{l}\mathrm{G}: \mathrm{F}, \mathrm{g} / \mathrm{g} \\
\text { day } 7 \text { to } 14\end{array}$ & 0.822 & 0.855 & 0.841 & 0.799 & 0.881 & 0.847 & 0.027 & 0.484 & 0.849 \\
\hline $\mathrm{ADG}, \mathrm{g} / \mathrm{d}$ & 338.000 & 333.000 & 354.000 & 322.000 & 311.000 & 324.000 & 17.000 & 0.243 & 0.810 \\
\hline ADFI, g/d & 516.000 & 512.000 & 479.000 & 421.000 & 434.000 & 451.000 & 20.000 & 0.002 & 0.134 \\
\hline $\begin{array}{l}\mathrm{G}: \mathrm{F}, \mathrm{g} / \mathrm{g} \\
\text { day } 0 \text { to } 14\end{array}$ & 0.652 & 0.651 & 0.735 & 0.796 & 0.719 & 0.726 & 0.038 & 0.057 & 0.093 \\
\hline $\mathrm{ADG}, \mathrm{g} / \mathrm{d}$ & 300.000 & 302.000 & 302.000 & 285.000 & 295.000 & 291.000 & 12.000 & 0.442 & 0.916 \\
\hline ADFI, $\mathrm{g} / \mathrm{d}$ & 417.000 & 415.000 & 389.000 & 364.000 & 375.000 & 379.000 & 13.000 & 0.007 & 0.154 \\
\hline $\mathrm{G}: \mathrm{F}, \mathrm{g} / \mathrm{g}$ & 0.717 & 0.729 & 0.777 & 0.794 & 0.787 & 0.773 & 0.020 & 0.011 & 0.069 \\
\hline
\end{tabular}

${ }^{a}$ Each least squares mean represents five observations. Experimental unit was the pen with six or nine pigs per pen

${ }^{\mathrm{b}} \mathrm{SID}=$ Standardized Ileal Digestible (SID)

${ }^{\mathrm{c}} \mathrm{ADG}=$ Average Daily Gain; ADFI = Average Daily Feed Intake; G:F = Gain: Feed

${ }^{\mathrm{d}} \mathrm{SEM}=$ Standard Error of the Mean

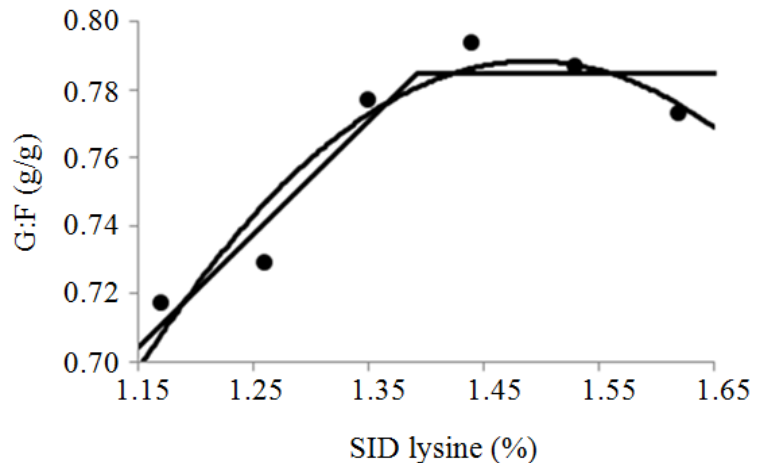

(a)

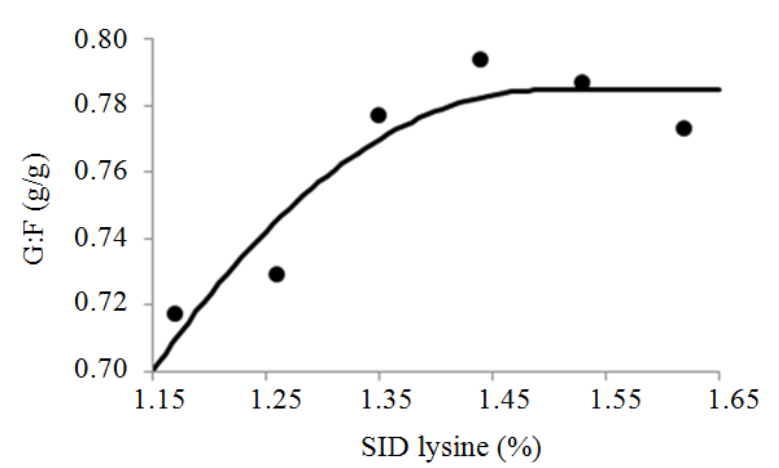

(b)

Fig. 1. Data points represent least squares means of six dietary treatments from five pens containing six or nine pigs per pen. Each regression model shows the Gain:Feed (G:F) of 6- to 10-kg weanling pigs relative to dietary Standardized Ileal Digestible (SID) lysine concentration. (a) Linear broken-line model indicated that the SID lysine requirement was $1.39 \%$ (standard error $=0.048)$ based on the following equation: $\mathrm{Y}=0.78-0.33 \times(1.39-\mathrm{X})$ where $\mathrm{X}$ is less than 1.39 , with $\mathrm{r}^{2}=0.913$ and $\mathrm{p}=0.025$. Quadratic model indicated that the SID lysine requirement was $1.42 \%$ (standard error $=0.038$ ), which value was obtained from $95 \%$ of the upper asymptotic value of the model: $\mathrm{Y}=0.79-0.78 \times(1.49-\mathrm{X})^{2}$, with $\mathrm{r}^{2}=0.909$ and $\mathrm{p}=0.027$. The intercept between the two models indicated that the SID lysine requirement was $1.42 \%$ (standard error $=0.006$ ). (b) Quadratic brokenline model indicated that the SID lysine requirement was $1.49 \%$ (standard error $=0.126$ ) based on the following equation: $\mathrm{Y}=$ $0.78-0.72 \times(1.49-\mathrm{X})^{2}$ where $\mathrm{X}$ is less than 1.49 , with $\mathrm{r}^{2}=0.874$ and $\mathrm{p}=0.044$

The maximal G:F above the break point (i.e., plateau line) was $0.785 \mathrm{~g} / \mathrm{g}$. In the quadratic model, the upper asymptotic value for maximal G:F of pigs $(0.789 \mathrm{~g} / \mathrm{g})$ was $1.49 \%$. Therefore, the SID lysine requirement was $1.42 \%$, which was determined by $95 \%$ of the upper asymptotic value. The SID lysine requirement derived from the former intercept value between the plateau line of linear broken-line model and quadratic model was $1.42 \%$. Based on the quadratic broken-line analysis for the SID lysine requirement, the optimal SID lysine requirement was $1.49 \%$ for the maximal $\mathrm{G}: \mathrm{F}(0.785 \mathrm{~g} / \mathrm{g})$ of pigs (Fig. 1b). Based on a mean ME concentration in diets, the SID lysine requirements were converted to $3.95,4.04,4.04$ and $4.24 \mathrm{~g} / \mathrm{Mcal} \mathrm{ME}$, respectively.

\section{Discussion}

Experimental diets were prepared to contain common feed ingredients for weanling pigs. We did not include antibiotics in order to prevent the 
overestimates in growth performance of pigs fed the diets containing the SID lysine below the requirement. However, growth performance obtained from the present experiment concurs with the previous research that included antibiotics (Schneider et al., 2010; Nemechek et al., 2012).

Dietary SID lysine concentrations were decided based on the values from the previous studies (Yi et al., 2006; Oresanya et al., 2007; Kendall et al., 2008; Schneider et al., 2010; Nemechek et al., 2012). The expected initial mean BW of pigs was approximately $7 \mathrm{~kg}$ but the mean BW at the beginning of the trial was $6.2 \mathrm{~kg}$.

During the first $7 \mathrm{~d}$ of trial, the ADG, ADFI and G:F were not affected by the dietary SID lysine concentration. The reason for this observation remains unclear; however, although NRC (2012) suggested that the estimated SID lysine requirement of 5 to 10 $\mathrm{kg}$ weanling pig was $1.50 \%$, it is possible that the suggested requirement may be underestimated for maximal growth of weanling pigs because of the lack of information. Therefore, dietary SID lysine concentration in diets might be insufficient to increase the growth performance of pigs.

From $d 7$ to 14 , while the ADG and G:F of pigs were not affected by dietary SID concentrations, the ADFI of pigs decreased as dietary SID concentration increased. During the overall period, the ADFI decreased and the G:F increased with increasing dietary SID lysine concentrations. In contrast to the present experiment, Kendall et al. (2008) reported that the ADFI of pigs was not affected by dietary lysine concentration if lysine was supplied by crystalline form. However, Nemechek et al. (2012) reported that graded concentration of SID lysine in diets by adding crystalline ${ }_{\mathrm{L}}$-lysine $\cdot \mathrm{HCl}$ decreased the ADFI of pigs and subsequently increased G:F, which agrees with the present data.

One of the factors affecting the requirements is statistical methodology to estimate the optimal dietary concentration of nutrient of interest (Baker, 1986). Differences in statistical models can contribute to the variation in estimating the requirements. Therefore, the SID lysine requirements determined in the present experiment were obtained by four different approaches in order to avoid the bias caused by the statistical analysis. Mean value for the SID lysine requirement was $1.43 \%$ (4.07 $\mathrm{g} / \mathrm{Mcal} \mathrm{ME})$, which was less than the estimated SID lysine requirement $(1.46 \% ; 4.15 \mathrm{~g} / \mathrm{Mcal} \mathrm{ME})$ calculated by the model suggested in NRC (2012), although it was within the range of values determined in the present experiment. The SID lysine requirements of the present experiment was also less than the values observed in other experiment reported by Nemechek et al. (2012) who suggested that the SID lysine requirement of 7to $14-\mathrm{kg}$ weanling pigs was $1.46 \%$ (4.55 g/Mcal ME) for maximal G:F of pigs. This difference may be attributed to several factors such as differences in genetic potential of pigs (Schneider et al., 2010) or immune stress caused by uncontrolled sanitary condition of experimental facility (Williams et al., 1997). Jones et al. (2014) reported that the SID lysine requirements of 6.6 - to $12.4-\mathrm{kg}$ pigs, ranging from 1.36 to $1.47 \%$ (from 3.84 to $4.19 \mathrm{~g} / \mathrm{Mcal} \mathrm{ME}$ ), were greater than estimated requirement suggested in NRC (2012). Systematic growth model should be established for accurate estimates of the SID lysine requirement for weanling pigs. Further research is needed to evaluate the effects of possible factors affecting the requirements of weanling pigs.

\section{Conclusion}

In conclusion, the SID lysine requirements for maximal $\mathrm{G}: \mathrm{F}$ of $6-$ to $10-\mathrm{kg}$ weanling pigs ranged from 1.39 to $1.49 \%$ (from 3.95 to $4.24 \mathrm{~g} / \mathrm{Mcal} \mathrm{ME}$ ). Mean value for the SID lysine requirement was $1.43 \%$ (4.07 g/Mcal ME), which was less than the estimated value of NRC (2012).

\section{Funding Information}

The authors are grateful for the support by Rural Development Administration (Suwon, Republic of Korea; PJ009340).

\section{Author's Contributions}

Chan Sol Park: Conducted the animal experiment and wrote most of the manuscript.

Beob Gyun Kim: Supervised the experimental work and manuscript preparation.

\section{Ethics}

The authors declared no ethical issues.

\section{References}

AOAC, 2005. Official methods of analysis. Association of Official Analytical Chemists.18th Edn., AOAC, Arlington, VA. ISBN-10: 0-935584-75-7

Baker, D.H. 1986. Problems and pitfalls in animal experiments designed to establish dietary requirements for essential nutrients. J. Nutrition, 116: 2339-2349. PMID: 3543259

Chung, T.K. and D.H. Baker, 1992. Ideal amino acid pattern for 10-kilogram pigs. J. Anim. Sci., 70: 3102-3111. PMID: 1429287

Cromwell, G.L., T.R. Cline, J.D. Crenshaw, T.D. Crenshaw and R.C. Ewan et al., 1993. The dietary protein and(or) lysine requirements of barrows and gilts. NCR-42 committee on swine nutrition. J. Anim. Sci., 71: 3460-3470. PMID: 8325811 
de Lange, C.F.M., S.H. Birkett and P.C.H. Morel, 2001. Protein, Fat and Bone Tissue Growth in Swine. In: Swine Nutrition. Lewins, A.J and L.L. Southern (Eds.), CRC Press, Washington, DC, ISBN-10: 0-8493-0696-5, pp: 65-81.

Jones, C.K., M.D. Tokach, J.L. Usry, C.R. Neill and J.F. Patience, 2014. Evaluating lysine requirements of nursery pigs fed low protein diets with different sources of nonessential amino acids. J. Anim. Sci., 92: 3460-3470. DOI: 10.2527/jas.2014-7018

Kendall, D.C., A.M. Gaines, G.L. Allee and J.L. Usry, 2008. Commercial validation of the true ileal digestible lysine requirement for eleven- to twentyseven-kilogram pigs. J. Anim. Sci., 86: 324-332. DOI: $10.2527 /$ jas.2007-0086

Kil, D.Y., B.G. Kim and H.H. Stein, 2013. Invited review: Feed energy evaluation for growing pigs. Asian-Australasian. J. Anim. Sci., 26: 1205-1217. DOI: 10.5713/ajas.2013.r.02

Kim, B.G. and M.D. Lindemann, 2007. A new spreadsheet method for the experimental animal allotment. J. Anim. Sci., 85: 218.

Kong, C. and O. Adeola, 2014. Invited review: Evaluation of amino acid and energy utilization in feedstuff for swine and poultry diets. Asian Aus. J. Anim. Sci., 27: 917-925.

DOI: 10.5713/ajas.2014.r.02

Lindemann, M.D. and B.G. Kim, 2007. Technical note: A model to estimate individual feed intake of swine in group feeding. J. Anim. Sci., 85: 972-975. DOI: $10.2527 /$ jas.2006-412

Nemechek, J.E., A.M. Gaines, M.D. Tokach, G.L. Allee and R.D. Goodband et al., 2012. Evaluation of standardized ileal digestible lysine requirement of nursery pigs from seven to fourteen kilograms. J. Anim. Sci., 90: 4380-4390. DOI: $10.2527 /$ jas.2011-5131

NRC, 2012. Nutrient Requirements of Swine. 11th Edn., National Academic Press, Washington, DC. ISBN-10: 0309224233
Oresanya, T.F., A.D. Beaulieu, E. Beltranena and J.F. Patience, 2007. The effect of dietary energy concentration and total lysine/digestible energy ratio on the growth performance of weaned pigs. Canadian J. Anim. Sci., 87: 45-55. DOI: $10.4141 /$ A05-064

Parr, T.M., B.J. Kerr and D.H. Baker, 2003. Isoleucine requirement of growing ( 25 to $45 \mathrm{~kg}$ ) pigs. J. Anim. Sci., 81: 745-752. PMID: 12661655

Robbins, K.R., A.M. Saxton and L.L. Southern, 2006. Estimation of nutrient requirements using broken-line regression analysis. J. Anim. Sci., 84: 3102-3111. PMID: 16582088

Schneider, J.D., M.D. Tokach, S.S. Dritz, J.L. Nelssen and J.M. DeRouchey et al., 2010. Determining the effect of lysine: Calorie ratio on growth performance of tento twenty-kilogram of body weight nursery pigs of two different genotypes. J. Anim. Sci., 88: 137-146. DOI: $10.2527 /$ jas.2008-1204

Stein, H.H., B. Sève, M.F. Fuller, P.J. Moughan and C.F.M. de Lange, 2007. Invited review: Amino acid bioavailability and digestibility in pig feed ingredients: Terminology and application. J. Anim. Sci., 85: 172-180. DOI: 10.2527/jas.2005-742

Wang, T.C. and M.F. Fuller, 1989. The optimal dietary amino acid pattern for growing pigs. 1. Experiments by amino acid deletion. Brit. J. Nutrition, 62: 77-89. DOI: 10.1079/bjn19890009

Williams, N.H., T.S. Stahly and D.R. Zimmerman, 1997. Effect of chronic immune system activation on the rate, efficiency and composition of growth and lysine needs of pigs fed from 6 to $27 \mathrm{~kg}$. J. Anim. Sci., 75: 2463-2471. PMID: 9303467

Yi, G.F., A.M. Gaines, B.W. Ratliff, P. Srichana and G.L. Allee et al., 2006. Estimation of the true ileal digestible lysine and sulfur amino acid requirement and comparison of the bioefficacy of 2-hydroxy-4(methylthio) butanoic acid and $\mathrm{DL}^{-}$-methionine in eleven- to twenty-six-kilogram nursery pigs. J. Anim. Sci., 84: 1709-1721. DOI: 10.2527/jas.2005-465 